\title{
Seasonal Patterns of Forage Availability in the Fescue Grasslands Under Contrasting Grazing Histories
}

\author{
Edward Bork, ${ }^{1}$ Walter Willms, ${ }^{2}$ Steven Tannas, ${ }^{3}$ and Mike Alexander ${ }^{4}$
}

Authors are ${ }^{1}$ Professor and ${ }^{3}$ Graduate Student, Department of Agriculture, Food, and Nutritional Science, University of Alberta, Edmonton, AB T6G 2P5, Canada; ${ }^{2}$ Research Scientist, Lethbridge Research Centre, Agriculture and Agri-Food Canada, Lethbridge, AB T1J 4B1, Canada; and ${ }^{4}$ Provincial Rangeland Specialist, Alberta Sustainable Resource Development, Lands Division, Pincher Creek, AB T0K 1 W0, Canada.

\begin{abstract}
Grazing by large herbivores has been shown to condition vegetation in a manner that improves grassland quality for subsequent herbivory. Fescue grasslands evolved with disturbance from fire and winter grazing by bison but are now grazed primarily by cattle during summer. We examined the effect of long-term summer grazing on the seasonal forage production and quality of fescue grasslands in an examination of the hypothesis that long-term grazing had conditioned fescue grasslands to benefit livestock. This hypothesis was examined by comparing, between grazed and ungrazed plots, the biomass and composition of herbage components, concentrations of nitrogen $(\mathrm{N})$ and acid detergent fiber (ADF) therein, and the ability of major plant types to maintain their biomass and quality throughout the growing season. The study was conducted in southern Alberta at five sites that had long-term exclosures $(20+\mathrm{yr})$ on grasslands that had been moderately grazed. Grazing had no effect on the $\mathrm{N}$ concentration of associated grasses, but grasses had lower $\mathrm{N}$ concentration than forbs. Concentrations of ADF followed a reciprocal trend to N. Grazing increased the mass of forbs from about $10 \%$ to $20 \%$ as a proportion of total biomass, which in turn, was not affected by grazing history. However, this grazing-induced shift to a higher quality vegetation type was not sufficient to affect total mass of $\mathrm{N}$ or total digestible nutrients at the community level. Rather than changes in current growth and quality, the predominant effect of summer grazing was in reducing litter mass, which also had the potential for affecting forage production and selection by herbivores. Finally, grazing reduced the relative contribution of rough fescue to total biomass by about $30 \%$, and despite no significant effect on the potential to support summer grazing, this change could reduce the quality of these grasslands for winter grazing.
\end{abstract}

\section{Resumen}

El Pastoreo por grandes herbívoros ha demostrado que mejora la vegetación incrementando la calidad de los pastizales para un pastoreo subsecuente. Los pastizales de Festucas evolucionaron con perturbaciones de fuego y pastoreo por el búfalo durante el invierno, pero ahora son pastoreados principalmente durante el verano por ganado doméstico. Examinamos el efecto a largo plazo del pastoreo de verano sobre la producción de forraje estacional y la calidad de los pastizales de Festuca, y probamos la hipótesis de que el pastoreo a largo plazo ha acondicionado los pastizales de Festuca en beneficio del ganado doméstico. Esta hipótesis se examinó por comparación entre parcelas pastoreadas y no pastoreadas, la biomasa y la composición de componentes del forraje, las concentraciones de nitrógeno (N) y fibra detergente ácido (ADF) y en la capacidad de la mayoría de tipos de plantas para mantener su biomasa y calidad a lo largo de la temporada de crecimiento. El estudio se realizó en el sur de Alberta en cinco sitios que tenían exclusiones a largo plazo (más de 20 años) en pastizales ha habían sido pastoreado moderadamente. El pastoreo no tuvo ningún efecto en la concentración de $\mathrm{N}$ de los pastos asociados, pero las gramíneas tenían una menor concentración de $\mathrm{N}$ que las herbáceas. Las concentraciones de ADF siguieron una tendencia recíproca al N. El pastoreo aumentó la masa de herbáceas de alrededor del 10\% al 20\% como proporción de la biomasa total, que a su vez, no se afectó por la historia de pastoreo. Sin embargo, este cambio inducido por el pastoreo a un tipo de vegetación de mejor calidad, no fue suficiente para afectar la masa total de No TDN a nivel de la comunidad. En lugar de los cambios en el crecimiento real y en la calidad, el efecto predominante de pastoreo de verano fue en la reducción de la masa del mantillo, que también tenía el potencial de afectar la producción de forraje y selección por herbívoros. Finalmente, el pastoreo redujo la contribución relativa de Festuca aproximadamente un $30 \%$, de la biomasa total a pesar de no mostrar ningún efecto significativo sobre el potencial de apoyar el pastoreo de verano, este cambio podría reducir la calidad de estos pastizales para el pastoreo durante el invierno.

Key Words: biomass, forage quality, litter, nitrogen concentration, Festuca campestris, species composition

\section{INTRODUCTION}

Funding for this work was provided by the Green Cover Canada Technical Assistance Program, as well as the University of Alberta.

Correspondence: Walter Willms, Lethbridge Research Centre, Agriculture and Agri-Food Canada, Box 3000, Lethbridge, AB T1J 4B1, Canada. Email: walter.willms@agr.gc.ca

Manuscript received 16 May 2011; manuscript accepted 2 October 2011.
Fescue grasslands evolved with regular disturbance from periodic fire (Wright and Bailey 1982) and winter grazing by bison (Morgan 1980), which set back woody vegetation and prevented large accumulations of litter (dead plant tissue). Presently, fires have been largely suppressed and cattle grazing in summer has become the primary disturbance. 
Fescue grasslands in southwestern Alberta are dominated by foothills rough fescue (Festuca campestris Rydb.). This species is a large caespitose plant with basal leaves that are highly sclerenchymatous, but it is relatively more preferred than plants of associated species in the community (Moisey et al. 2006). However, rough fescue is sensitive when grazed during the growing season and will readily decline with heavy grazing pressure (Willms et al. 1985). In order to maintain this species, fescue grasslands are managed with a conservative stocking rate, or use is delayed into late summer or fall. Grazing of any intensity ultimately affects the form and function of fescue grasslands through defoliation, trampling, and nutrient deposition.

Grazing can also affect the nutritional quality of selected livestock diets by altering the relative abundance of forage species, changing phenological development of plants by stimulating new leaf growth, and enriching available nutrients through manure and urine deposition, or by altering the mass of litter (including dead plant material produced the previous year), among other factors (see Bailey et al. 1996 for a review). These effects may be cumulative and persistent with a range of possible consequences that affect herbivory. For example, Altai wildrye (Leymus angustus [Trin.] Pilg.) cut in July had greater concentrations of crude protein and phosphorus, and less acid detergent fiber (ADF) in the following January than plants that had not been cut (Willms 1991). Moreover, the barrier effect of litter on forage selection by livestock is well documented (Willms et al. 1980a; Ganskopp et al. 1992; Moisey et al. 2006). Combined, these effects can change large-scale ungulate movements (McNaughton 1976), with the potential for grazing to condition grasslands to benefit subsequent herbivory.

A series of livestock exclosures within moderately grazed pastures provided an opportunity to test the hypothesis that longterm grazing had conditioned fescue grasslands to benefit livestock. Therefore, we initiated a study to answer questions of how summer grazing affects the nutritional quality of the standing crop in fescue grasslands over an extended grazing period and whether individual biomass components respond similarly. More specifically, we compared the biomass and composition of major forage types between grazed and ungrazed communities, assessed associated concentrations of nitrogen $(\mathrm{N})$ and ADF in the same, and quantified changes in forage availability and quality throughout the growing season.

\section{METHODS}

\section{Study Areas}

Five representative sites from across the fescue grasslands of southern Alberta were selected for the study. The sites included: Waldron, Ross Lake, Cypress Hills, Castle Mountain, and Dutch Creek/Lower Livingstone (Table 1). The latter three are located in the Montane natural subregion on Orthic Black Chernozem soils with shallow to gravel, clay loam to loam, and loam to sandy loam textures, respectively. The Waldron and Ross Lake sites are located in the Foothills Fescue natural subregion also on Orthic Black Chernozems with loamy to clay and gravely textures, respectively. Elevations among sites range from $1225 \mathrm{~m}$ to $1500 \mathrm{~m}$ above sea level (Table 1). Precipitation in southern Alberta from April to August was at least two times greater in 2005 than in 2006, the latter of which was $15 \%$ below normal (Table 2 ).

All sites selected for sampling included exclosures (approximately $10 \times 20 \mathrm{~m}$ in size) that had been protected from grazing for 20 or more years. This allowed pairwise comparison between grazed and ungrazed areas within each ecosite, and facilitated assessment of grazing impacts on seasonal production and nutritional quality of vegetation. All sites had a history of annual grazing from mid-June to mid-October at moderate stocking rates in accordance with the Alberta Public Lands recommendations for the Montane (Willoughby et al. 2005 ) and Foothills Fescue (Adams et al. 2003) subregions. The recommended stocking rate is set to utilize about $26 \%$ of longterm forage production (Adams et al. 2003). The grazing season normally begins in early June and ends in October, although it may be extended into winter.

\section{Field Sampling}

Vegetation biomass was sampled at each site four times annually in 2005 and 2006. Sampling periods were selected to evaluate grazing potential in early summer (June 5), midsummer (July 15), late summer (August 31), and the dormant season (October 15). In June 2005, sampling at Cypress Hills and Ross Lake was not completed due to inaccessibility from flooding. Annual sampling occurred at four randomly selected plots (subsamples) within each treatment (grazed and ungrazed) and site for a total of 40 plots. Each plot, in turn, consisted of four $0.5 \times 0.5 \mathrm{~m}$ quadrats systematically arranged within a square $(1.5 \times 1.5 \mathrm{~m})$ to avoid overlap, with a different quadrat sampled each month throughout the year. The location of sampling plots was rerandomized annually. All quadrats in the grazed treatment were protected from grazing with a temporary exclosure cage $(1.5 \times 1.5 \mathrm{~m})$.

The vegetation in individual quadrats was clipped to ground level and separated into rough fescue, subdominant grasses (specifically Parry's oatgrass [Danthonia parryi Scribn.] and/or Idaho fescue [Festuca idahoensis Elmer]), other grasses, forbs, and litter. Litter was represented by all biomass produced prior to the current year. Therefore, all other components were represented by vegetation produced in the year of sampling. "Other grasses" included Junegrass (Koeleria macrantha [Ledeb.] Schult.); wheatgrasses (included northern wheatgrass [Elymus lanceolatus \{Scribn. \& J.G. Sm.\} Gould] and western wheatgrass [Pascopyrum smithii \{Rydb.\} A. Löve]); speargrasses (included needleandthread [Hesperostipa comata \{Trin. \& Rupr.\} Barkworth], porcupine grass [Hesperostipa spartea \{Trin.\} Barkworth], Richardson's needlegrass [Achnatherum richardsonii \{Link\} Barkworth] and green needlegrass [Nassella viridula \{Trin.\} Barkworth]); bluegrasses (included numerous Poa spp. but primarily Kentucky bluegrass $[P$. pratensis L.]), brome grasses (includes fringed brome [Bromus ciliatus L.], smooth brome [Bromus inermis Leyss. subsp. inermis] and Pumpelly's brome [Bromus inermis Leyss. subsp. pumpellianus \{Scribn.\} Wagnon]); and others. Dominant forbs included three-flowered avens (Geum triflorum Pursh), silvery lupine (Lupinus argenteus Pursh), slender blue beard tongue (Penstemon procerus Douglas ex Graham), buffalo-bean (Thermopsis rhombifolia [Nutt. ex Pursh] Nutt. ex Richardson), bedstraw (Galium boreale L.), and smooth 
Table 1. Description of five research sites ${ }^{1}$ in the fescue grasslands of southern Alberta.

\begin{tabular}{|c|c|c|c|c|c|c|c|c|c|}
\hline \multirow[b]{2}{*}{ Site } & \multirow[b]{2}{*}{ Geographic coordinates } & \multirow[b]{2}{*}{ Elevation (m) } & \multirow[b]{2}{*}{ Soil (texture) } & \multirow{2}{*}{$\begin{array}{c}\text { Range } \\
\text { health }{ }^{2}(\%)\end{array}$} & \multirow{2}{*}{$\begin{array}{l}\text { Years of } \\
\text { exclosure }\end{array}$} & \multicolumn{2}{|c|}{$\begin{array}{l}\text { Long-term production } \\
\qquad\left(\mathrm{kg} \cdot \mathrm{ha}^{-1}\right)\end{array}$} & \multicolumn{2}{|c|}{$\begin{array}{l}\text { Litter mass } \\
\left(\mathrm{kg} \cdot \mathrm{ha}^{-1}\right)\end{array}$} \\
\hline & & & & & & Exclosure & Grazed $^{3}$ & Exclosure & Grazed $^{3}$ \\
\hline Cypress Hills & lat $110^{\circ} 5^{\prime} 42^{\prime \prime} \mathrm{N}$, long $49^{\circ} 34^{\prime} 55^{\prime \prime} \mathrm{W}$ & 1402 & Silt loam & $83 / 83$ & 33 & 1798 & 2405 & 3617 & 3578 \\
\hline $\begin{array}{l}\text { Dutch Creek/Lower } \\
\text { Livingstone }\end{array}$ & lat $114^{\circ} 23^{\prime} 17^{\prime \prime} \mathrm{N}$, long $49^{\circ} 54^{\prime} 22^{\prime \prime} \mathrm{W}$ & 1450 & Loam to silt loam & $100 / 100$ & $57+$ & 1392 & 1244 & 1298 & 733 \\
\hline Castle River & lat $114^{\circ} 19^{\prime} 12^{\prime \prime} \mathrm{N}$, long $49^{\circ} 25^{\prime} 19^{\prime \prime} \mathrm{W}$ & 1343 & Clay loam & $100 / 70$ & 57 & 2649 & 3428 & 3646 & 1331 \\
\hline Ross Lake & lat $112^{\circ} 53^{\prime} 35^{\prime \prime} \mathrm{N}$, long $49^{\circ} 07^{\prime} 05^{\prime \prime} \mathrm{W}$ & 1225 & Gravely & -4 & - & - & - & - & - \\
\hline Waldron & lat $114^{\circ} 06^{\prime} 50^{\prime \prime} \mathrm{N}$, long $49^{\circ} 48^{\prime} 04^{\prime \prime} \mathrm{W}$ & 1280 & Clay & $96 / 88$ & 20 & 1621 & 1705 & 2217 & 1386 \\
\hline
\end{tabular}

${ }^{1}$ Site descriptions were provided by the Benchmark Monitoring Program of the Alberta Department of Sustainable Resource Development (Moisey and Adams 2001).

${ }^{2}$ Range health scores under protected and grazed conditions, respectively.

${ }^{3}$ Protected with a mobile cage during the grazing season that was moved annually.

${ }^{4}$ Data not available.

aster (Symphyotrichum laeve [L.] A. Löve \& D. Löve var. geyeri [A. Gray] G.L. Nesom).

\section{Forage Processing and Analysis}

All vegetation components were initially air-dried and stored until they could be oven-dried at $60^{\circ} \mathrm{C}$ for $72 \mathrm{~h}$ and weighed. All components, except litter, were then ground to pass a 1-mm mesh. Plot subsamples within a sampling period were then combined by site and treatment and analyzed for $\mathrm{N}$ and ADF concentration. ADF analysis was completed using the filter-bag technique (ANKOM filter bag technique; ANKOM Technology Corp, Fairport, NY), and ADF values were used to derive total digestible nutrients (TDN; i.e., $100-\mathrm{ADF}=\mathrm{TDN}) . \mathrm{N}$ concentrations (\%) were determined using a LECO $\mathrm{N}$ autoanalyzer (Leco Corporation, St Joseph, MI). N yields (NY) were calculated by multiplying the biomass $\left(\mathrm{kg} \cdot \mathrm{ha}^{-1}\right)$ of each of the four vegetation components by their $\mathrm{N}$ concentration.

\section{Data Analysis}

The effect of grazing treatment, sampling month, and year on vegetation biomass (by component and total), proportion of total biomass represented by each vegetation component, and litter mass, as well as N, NY, and TDN, were analyzed using a mixed model (Mixed Procedure, SAS, Version 9.1.3, SAS Institute Inc, Cary, NC, USA). Effects of grazing, month, and year, together with their interactions were considered fixed effects, with site (blocks) being random. Both month and year were treated as repeated measures. The optimal covariance structure matrix (autoregressive, heterogeneous autoregressive, compound symmetry, and heterogeneous compound symmetry) was selected using Akaike's Information Criterion. All data were tested for normality (Shapiro-Wilk test) and the residuals were plotted and examined for outliers. If necessary, outliers were either removed or the data were adjusted using log transformation $(+1)$; the transformation was usually applied when numerous values were zero. For all analyses, treatment means were separated using the Fisher's Protected LSD test with the Bonferonni adjustment $(P=0.05)$. Where the 3 -way interaction (grazing $\times$ month $\times$ year) was significant, the analysis was repeated by year for clarity, and means of significant effects were reported.

Although the five sites were representative of the fescue prairie and their pooled analyses provided a broad overview of grazing effects at the community level, we also recognize that site differences may exist in the response to grazing due to variable grazing intensity in the past combined with edaphic factors. Therefore, an analysis of variance (ANOVA) was performed by site on total and rough fescue biomass, with the four sampling plots (subsamples) treated as replicates with the assumption that they represented experimental error. In order to simplify this analysis, we assessed only the month of peak standing crop (i.e., July), which represented the aboveground annual net primary production (ANPP).

Empirical relationships on the effect of litter mass on ANPP and rough fescue (percentage of proportion and biomass), as well as the effect of the percentage of proportion of rough fescue on ANPP, were examined with simple regression for the month of July only (Reg Procedure, SAS, Version 9.1.3, SAS Institute Inc). Regressions were done separately by year because of the potential effect that variable growing conditions would have on that relationship. We also calculated these relationships

Table 2. Growing season precipitation (April to August) during 2005 and 2006 at four meteorological sites in southern Alberta and their distances from the study sites.

\begin{tabular}{|c|c|c|c|c|c|c|c|c|}
\hline \multirow[b]{2}{*}{ Meteorological site } & \multicolumn{5}{|c|}{ Study site } & \multicolumn{3}{|c|}{ Precipitation } \\
\hline & Cypress Hill & Livingstone & Castle River & Ross Lake & Waldron & 2005 & 2006 & 30-yr average \\
\hline & & & stance (k & $\cdots$ & & . & & \\
\hline Beaver Mines & 295 & 55 & 12 & 122 & 37 & 752 & 359 & 398 \\
\hline Pincher Creek & 282 & 55 & 26 & 111 & 32 & 842 & 304 & $370^{1}$ \\
\hline Lethbridge & 194 & 122 & 113 & 35 & 98 & 534 & 205 & 257 \\
\hline Medicine Hat & 66 & 263 & 267 & 146 & 244 & 296 & 215 & 245 \\
\hline
\end{tabular}

${ }^{1}$ Average of 8 yr (2000 to 2007). 
Table 3. Effects of grazing treatment and sampling time (month and year) on the biomass of vegetation components, within fescue grasslands of southern Alberta.

\begin{tabular}{|c|c|c|c|c|c|c|c|c|c|c|c|c|}
\hline \multirow[b]{2}{*}{ Year } & \multirow[b]{2}{*}{ Month } & & \multicolumn{5}{|c|}{ Grasses } & \multirow{2}{*}{\multicolumn{2}{|c|}{ Forbs $^{1}$}} & & & \multirow[b]{2}{*}{ Total } \\
\hline & & & \multicolumn{2}{|c|}{ Rough fescue } & \multicolumn{2}{|c|}{$\begin{array}{l}\text { arry's oatgrass/ } \\
\text { Idaho fescue }\end{array}$} & Other $^{1}$ & & & & & \\
\hline & & & --------- & ----- & - & ------' & ------Bior & -2) ------ & ----------- & ------------ & ---------- & ----------- \\
\hline \multirow[t]{7}{*}{ Wet - 2005} & June & & $144 B^{2}$ & & $0 \mathrm{~A}$ & & $37 \mathrm{AB}$ & & $23 \mathrm{~A}$ & & & $201 A B$ \\
\hline & July & & $148 \mathrm{~B}$ & & $19 \mathrm{~B}$ & & $28 \mathrm{~A}$ & & $30 \mathrm{~B}$ & & & $231 \mathrm{~B}$ \\
\hline & August & & $135 \mathrm{AB}$ & & $12 \mathrm{AB}$ & & $50 \mathrm{~B}$ & & $31 \mathrm{AB}$ & & & 233 B \\
\hline & October & & $96 \mathrm{~A}$ & & $7 \mathrm{AB}$ & & $36 \mathrm{AB}$ & & $19 \mathrm{AB}$ & & & $164 \mathrm{~A}$ \\
\hline & SEM & & 15.4 & & 3.2 & & 9.7 & & 5.0 & & & 15.5 \\
\hline & Year & & 131 & & 9 & & 38 & & 26 & & & 207 \\
\hline & & & & & & & & Grazed & & Ungrazed & & \\
\hline \multirow[t]{7}{*}{ Dry - 2006} & June & & $75 \mathrm{~A}$ & & $13 \mathrm{~A}$ & & $20 \mathrm{~A}$ & $37 \mathrm{~A}$ & & $16 \mathrm{~A}$ & & $134 \mathrm{~A}$ \\
\hline & July & & $116 \mathrm{~B}$ & & $23 \mathrm{~A}$ & & $35 \mathrm{~B}$ & $76 \mathrm{~B}$ & & $29 \mathrm{~B}$ & & 234 B \\
\hline & August & & $87 \mathrm{~A}$ & & $20 \mathrm{~A}$ & & $28 \mathrm{AB}$ & $25 \mathrm{~A}$ & & $13 \mathrm{~A}$ & & $155 \mathrm{~A}$ \\
\hline & October & & $123 \mathrm{~B}$ & & $13 \mathrm{~A}$ & & $37 \mathrm{AB}$ & $33 \mathrm{~A}$ & & $16 \mathrm{~A}$ & & $197 \mathrm{~B}$ \\
\hline & SEM & & 11.0 & & 3.6 & & 7.1 & 3.8 & & & & 15.2 \\
\hline & Year & & 100 & & 17 & & 30 & 31 & & & & 180 \\
\hline & & Grazed & Ungrazed & Grazed & Ungrazed & Grazed & Ungrazed & Grazed & & Ungrazed & Grazed & Ungrazed \\
\hline \multicolumn{13}{|l|}{ 2005-2006 } \\
\hline \multirow[t]{2}{*}{ Treatment } & Overall & $95 \mathrm{a}^{3}$ & $136 \mathrm{~b}$ & $14 \mathrm{a}$ & $13 \mathrm{a}$ & $43 \mathrm{a}$ & $23 \mathrm{a}$ & $38 \mathrm{~b}$ & & $19 \mathrm{a}$ & $195 \mathrm{a}$ & $192 \mathrm{a}$ \\
\hline & SEM & & 13.0 & & 2.3 & & 8.2 & & & 3.0 & & 13.9 \\
\hline
\end{tabular}

${ }^{1}$ See Methods for a listing of plant species.

${ }^{2}$ Means within a year and column that have the same uppercase letter, or have no letter, are not different $(P>0.05)$.

${ }^{3}$ Paired means within a row having the same lowercase letter are not different $(P>0.05)$.

by individual site as well as pooled across sites. We recognize that site could have a significant effect on those relationships and analyzing them at that scale could contribute useful interpretation at the landscape scale.

Finally, temporal changes in the concentration of $\mathrm{N}$ and ADF from each plot (site $\times$ treatment $\times$ month) in each vegetation component over the study period were examined across sampling periods each year using regression (Reg Procedure, SAS, Version 9.1.3, SAS Institute Inc). The resulting intercepts and coefficients were then analyzed independently to test for the effects of vegetation component, grazing treatment, and sampling year in a mixed model ANOVA similar to the one described above.

\section{RESULTS}

Grazed communities had lower $(P<0.05)$ biomass of rough fescue but greater $(P<0.05)$ forb biomass than protected communities, resulting in an equivalent $(P>0.05)$ total biomass between treatments (Tables 3 and 4). However, grazing increased forbs only in the dry year of 2006 $(P<0.05)$ and not in the wet year of $2005(P>0.05$; Table 3$)$. Although the 3-way interaction of treatment, year, and month was also significant $(P=0.045)$ for the subdominant grasses (Table 4), an analysis of the data by year did not reveal a treatment effect or an effect of month by treatment. Therefore, no further subdivision of the data (Table 3) was required. The

Table 4. Statistical analyses (ANOVA) on the effects of grazing treatment and sampling time (month and year) on the biomass of vegetation components.

\begin{tabular}{|c|c|c|c|c|c|}
\hline \multirow[b]{2}{*}{ Source of variation ${ }^{1}$} & \multicolumn{3}{|c|}{ Grasses } & \multirow[b]{2}{*}{ Forbs $^{2}$} & \multirow[b]{2}{*}{ Total } \\
\hline & Rough fescue & $\begin{array}{c}\text { Parry's oatgrass/Idaho } \\
\text { fescue }\end{array}$ & Other ${ }^{2}$ & & \\
\hline & 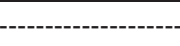 & "--------------- & obability & 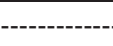 & ------- \\
\hline $\mathrm{T}$ & 0.042 & 0.850 & 0.108 & $<0.001$ & 0.873 \\
\hline M & 0.046 & $<0.001$ & 0.602 & $<0.001$ & 0.001 \\
\hline $\mathrm{T} \times \mathrm{M}$ & 0.076 & 0.851 & 0.311 & 0.385 & 0.614 \\
\hline Y & 0.032 & 0.021 & 0.246 & 0.116 & 0.017 \\
\hline $\mathrm{T} \times \mathrm{Y}$ & 0.694 & 0.411 & 0.472 & 0.068 & 0.258 \\
\hline$M \times Y$ & $<0.001$ & 0.268 & 0.001 & $<0.001$ & $<0.001$ \\
\hline $\mathrm{T} \times \mathrm{Y} \times \mathrm{M}$ & 0.600 & 0.045 & 0.672 & $<0.001$ & 0.175 \\
\hline
\end{tabular}

${ }^{1} \mathrm{~T}$ indicates treatment; $\mathrm{M}$, month; $\mathrm{Y}$, year.

${ }^{2}$ See Methods for a listing of plant species. 
Table 5. Effects of grazing treatment and sampling time (month and year) on the proportion of green aboveground standing crop of rough fescue, subdominant grasses (Parry oatgrass/Idaho fescue), and forbs within fescue grasslands of southern Alberta.

\begin{tabular}{|c|c|c|c|c|}
\hline & Rough fescue & Parry's oatgrass/Idaho fescue & Other $^{1}$ & Forbs $^{1}$ \\
\hline \multicolumn{5}{|c|}{ portion --- } \\
\hline June & 0.63 & $0.03 A^{2}$ & 0.17 & $0.16 \mathrm{AB}$ \\
\hline July & 0.56 & $0.07 \mathrm{C}$ & 0.15 & $0.18 \mathrm{~B}$ \\
\hline August & 0.56 & $0.09 \mathrm{C}$ & 0.20 & $0.13 \mathrm{~A}$ \\
\hline October & 0.61 & $0.06 \mathrm{~B}$ & 0.22 & $0.12 \mathrm{~A}$ \\
\hline SEM & 0.043 & 0.010 & 0.038 & 0.019 \\
\hline \multicolumn{5}{|l|}{ Treatment } \\
\hline Grazed & $0.49 \mathrm{~A}$ & 0.07 & 0.24 & $0.19 \mathrm{~B}$ \\
\hline Ungrazed & $0.69 \mathrm{~B}$ & 0.06 & 0.13 & $0.10 \mathrm{~A}$ \\
\hline SEM & 0.049 & 0.009 & 0.044 & 0.020 \\
\hline \multicolumn{5}{|c|}{ Source of variation ${ }^{3}$} \\
\hline $\mathrm{T}$ & 0.012 & 0.696 & 0.110 & 0.006 \\
\hline M & 0.301 & 0.002 & 0.263 & 0.035 \\
\hline $\mathrm{T} \times \mathrm{M}$ & 0.275 & 0.887 & 0.383 & 0.685 \\
\hline Y & 0.230 & 0.001 & 0.515 & 0.147 \\
\hline $\mathrm{T} \times \mathrm{Y}$ & 0.636 & 0.289 & 0.532 & 0.608 \\
\hline$M \times Y$ & 0.305 & 0.223 & 0.023 & 0.208 \\
\hline $\mathrm{T} \times \mathrm{Y} \times \mathrm{M}$ & 0.781 & $0.003^{4}$ & 0.717 & 0.614 \\
\hline
\end{tabular}

${ }^{1}$ See Methods for a listing of plant species.

${ }^{2}$ Means within a subset of a column that have the same uppercase letter, or have no letter, are not different $(P>0.05)$.

${ }^{3} \mathrm{~T}$ indicates treatment; $\mathrm{M}$, month; $\mathrm{Y}$, year.

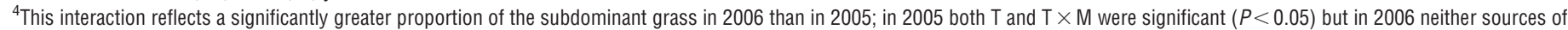
variation were significant $(P>0.05)$.

biomass of all individual vegetation components were affected $(P<0.05)$ by month of sampling or by its interaction with year (Tables 3 and 4). Temporal changes in biomass throughout the year were reflected by a decrease $(P<0.05)$ in forbs after July and an increase of subdominant grasses $(P<0.05)$ from June to August as a proportion of total biomass (Table 5). However, the proportion of total biomass comprising rough fescue and other grasses remained stable $(P>0.05)$.

Litter mass was affected $(P<0.05)$ by the main effects of grazing and month of sampling, as well as by their interactions with year. Examination of these data by year indicated that grazing, month, and their interaction were significant in 2005 $(P<0.05)$, whereas in 2006 only the main effects were significant $(P<0.05$; Table 6$)$. Averaged over both years, litter mass in the grazed treatment was only $21 \%$ that found in the ungrazed treatment (Table 6).

ANPP and rough fescue biomass measured at peak standing crop (July), were both affected by grazing and its interaction with site (Table 7). ANPP in grazed and ungrazed communities were similar $(P>0.05)$ at Castle River, Cypress Hills, and Livingstone, but was smaller $(P<0.05)$ in the grazed treatment at Ross Lake and larger $(P<0.05)$ in the grazed treatment at Waldron. Rough fescue biomass was similar $(P>0.05)$ in grazed and ungrazed treatments at Cypress Hills, Livingstone, and Waldron, but was greater $(P<0.05)$ in the ungrazed treatment at Castle River and Ross Lake. ANPP at each site under grazing was ranked as follows: Waldron $>$ Castle River $>($ Ross Lake $=$ Cypress Hills $)>$ Livingstone, whereas in the ungrazed treatment it was Ross Lake $>$ Castle River $>$
Waldron $>($ Cypress Hills $=$ Livingstone $) ;$ Table 7). Ranked abundance of rough fescue biomass among grazed treatments at each site was $($ Ross Lake $=$ Cypress Hills $=$ Waldron $=$ Castle River) $>$ Livingstone, and within the ungrazed treatment it was $($ Ross Lake $=$ Castle River $)>($ Waldron $=$ Cypress Hills $)>$ Livingstone (Table 7).

We did not detect any effect of litter $\left(\mathrm{X}, \mathrm{g} \cdot \mathrm{m}^{-2}\right)$ on ANPP $\left(\mathrm{Y}, \mathrm{g} \cdot \mathrm{m}^{-2}\right)$ in any year when analyzed over all sites $(P>0.05)$. However, in 2005 this relationship was positive at the Livingstone and Ross Lake sites $(b=0.51$ and 1.01, respectively; $P<0.05)$ but marginally negative at the Waldron site $(b=-0.35 ; P=0.06)$. In 2006, the relationship between litter and ANPP was marginally negative at the Castle River and Waldron sites $(b=-0.34$ and -0.59 , respectively; $P=0.07$ for both).

ANPP $\left(\mathrm{g} \cdot \mathrm{m}^{-2}\right)$ was weakly linked to the proportion of rough fescue ( $\%$ of ANPP) over all sites in $2005(P=0.07)$ but not in $2006(P=0.12)$. In 2005, this relationship assessed within sites was also inconsistent, with positive associations observed at Castle River and Ross Lake $(b=0.95$ and 3.73, respectively; $P<0.05$ for both sites) and a negative association at Waldron $(b=-3.24, P=0.01)$. In 2006, all significant relationships were negative (i.e., at the Cypress Hills, Castle River, and Waldron sites $b=-0.78,-1.21$, and -2.35 , respectively; $P<0.05$ ).

Litter mass $\left(\mathrm{g} \cdot \mathrm{m}^{-2}\right)$ was positively $(P<0.01)$ linked with the proportion of rough fescue ( $\%$ of ANPP) and rough fescue biomass $\left(\mathrm{g} \cdot \mathrm{m}^{-2}\right)$ across all sites and in both years $(\mathrm{Y}=$ proportion of rough fescue, 2005, $b=0.10 ; 2006, b=0.17$; $\mathrm{Y}=$ rough fescue biomass, 2005, $\mathrm{b}=0.74 ; 2006, \mathrm{~b}=0.44)$. 
Table 6. Effects of grazing treatment and sampling time (month and year) on litter biomass within fescue grasslands of southern Alberta.

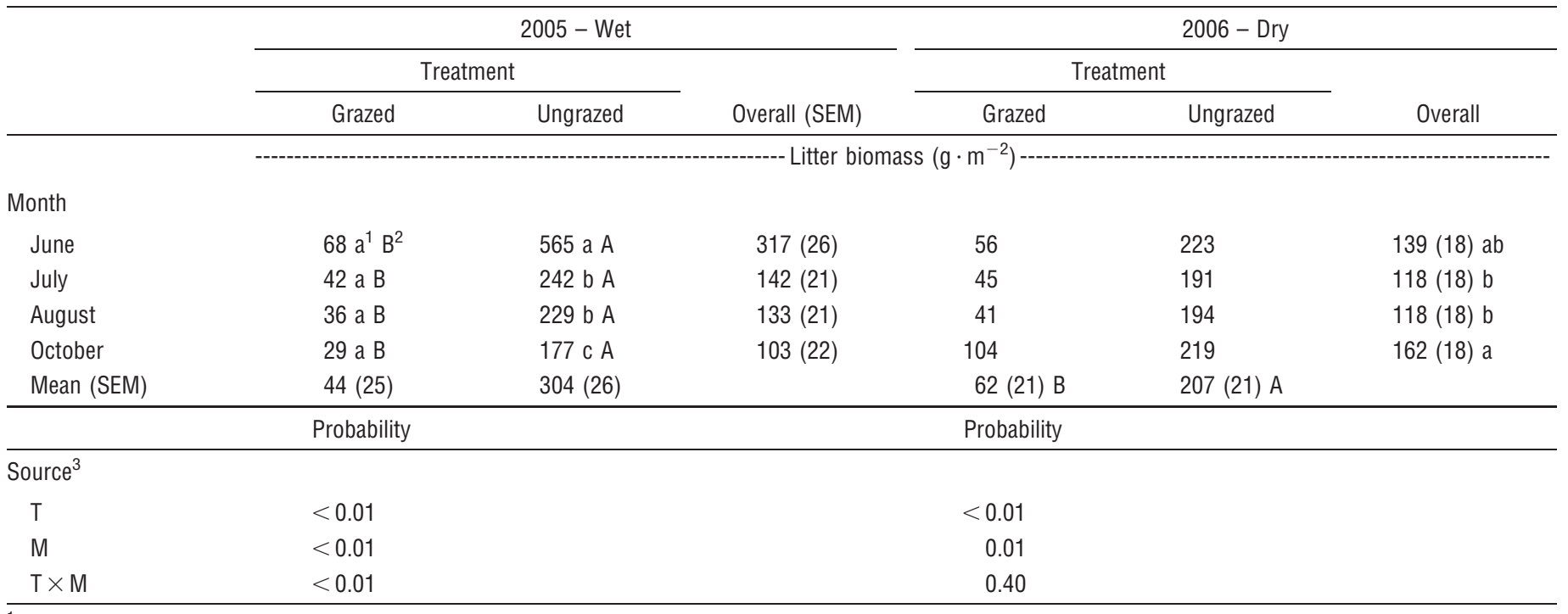

${ }^{1}$ Means within a column having the same lowercase letter are not different $(P>0.05)$.

${ }^{2}$ Paired means within a subset of a row that have the same uppercase letter are not different $(P>0.05)$.

${ }^{3} \mathrm{~T}$ indicates treatment; $\mathrm{M}$, month; $\mathrm{Y}$, year.

These relationships were generally consistent among sites (data not shown).

Forbs had a greater $(P<0.05)$ concentration of $\mathrm{N}$ than grasses in June (as denoted by the intercept values in Table 8), but exhibited the most rapid loss $(P<0.05)$ of $\mathrm{N}$ over the summer. Despite this, forbs were still projected to have about $11.8 \mathrm{mg} \cdot \mathrm{g}^{-1}$ of $\mathrm{N}$ by the final sampling time. In contrast, rough fescue exhibited a rapid decline in $\mathrm{N}$ concentration and had a final estimated value of $7.8 \mathrm{mg} \cdot \mathrm{g}^{-1}$. Grazing had no effect $(P>0.05)$ on $\mathrm{N}$ concentration or rates of $\mathrm{N}$ decline (Table 8).

Changes in the concentration of ADF followed a reciprocal trend to that of N. Grazing had no effect $(P>0.05)$ on either the ADF concentration in June (intercept) or its rate of seasonal increase (Table 8). Forbs had the lowest $(P<0.05)$ ADF concentration in June and exhibited the greatest $(P<0.05)$

Table 7. Effect of sampling site on the response to grazing treatment of rough fescue biomass and ANPP, ${ }^{1}$ measured in July, within the fescue grasslands of southern Alberta.

\begin{tabular}{|c|c|c|c|c|}
\hline \multirow[b]{3}{*}{ Site } & \multicolumn{2}{|c|}{ Rough fescue } & \multicolumn{2}{|c|}{ ANPP } \\
\hline & \multicolumn{2}{|c|}{ Treatment } & \multicolumn{2}{|c|}{ Treatment } \\
\hline & Grazed & Ungrazed & Grazed & Ungrazed \\
\hline & --------- & - & ---------- & ------ \\
\hline \multicolumn{5}{|l|}{ Sampling site } \\
\hline Cypress Hills & $106 a^{2} A^{3}$ & 152 b A & $200 \mathrm{~b} \mathrm{~A}$ & $180 \mathrm{~d} \mathrm{~A}$ \\
\hline Livingstone & $45 \mathrm{~b} \mathrm{~A}$ & $74 \mathrm{C} \mathrm{A}$ & $128 \mathrm{~d} \mathrm{~A}$ & $171 \mathrm{~d} \mathrm{~A}$ \\
\hline Castle River & 84 a B & 199 a A & $260 \mathrm{CA}$ & 264 b A \\
\hline Ross Lake & 109 a B & 228 a A & 206 C B & 303 a $A$ \\
\hline Waldron & 105 a $A$ & 159 b A & 366 a $A$ & 230 c B \\
\hline SEM & \multicolumn{2}{|c|}{13} & \multicolumn{2}{|c|}{10} \\
\hline \multicolumn{5}{|c|}{ Source of variation } \\
\hline $\mathrm{T}$ & \multicolumn{2}{|c|}{$<0.01$} & \multicolumn{2}{|c|}{0.68} \\
\hline Y & \multicolumn{2}{|c|}{$<0.01$} & \multicolumn{2}{|c|}{0.45} \\
\hline $\mathrm{Y} \times \mathrm{T}$ & \multicolumn{2}{|c|}{0.30} & \multicolumn{2}{|c|}{0.05} \\
\hline S & \multicolumn{2}{|c|}{$<0.01$} & \multicolumn{2}{|c|}{$<0.01$} \\
\hline $\mathrm{T} \times \mathrm{S}$ & \multicolumn{2}{|c|}{$<0.01$} & \multicolumn{2}{|c|}{$<0.01$} \\
\hline $\mathrm{Y} \times \mathrm{S}$ & \multicolumn{2}{|c|}{$<0.01$} & \multicolumn{2}{|c|}{0.27} \\
\hline $\mathrm{T} \times \mathrm{Y} \times \mathrm{S}$ & \multicolumn{2}{|c|}{$<0.01$} & \multicolumn{2}{|c|}{0.50} \\
\hline
\end{tabular}

${ }^{1}$ ANPP indicates aboveground net primary production; $T$, treatment; $\mathrm{Y}$, year; $\mathrm{S}$, site.

${ }^{2}$ Means in a column with the same lowercase letter are not different $(P>0.05)$.

${ }^{3}$ Paired means within a subset of a row having the same uppercase letters are not different $(P>0.05)$. 
Table 8. Effects of vegetation component and grazing treatment on the linear trend of nitrogen and acid detergent fiber concentration over the period June to October within fescue grasslands of southern Alberta.

\begin{tabular}{|c|c|c|c|c|}
\hline \multirow[b]{2}{*}{ Vegetation component } & \multicolumn{2}{|c|}{ Nitrogen $\left(\mathrm{mg} \cdot \mathrm{g}^{-1}\right)$} & \multicolumn{2}{|c|}{ Acid detergent fiber $\left(\mathrm{mg} \cdot \mathrm{g}^{-1}\right)$} \\
\hline & Intercept & Coefficient & Intercept & Coefficient \\
\hline Rough fescue & $15.4 A^{2}$ & $-1.90 \mathrm{~B}$ & $356 \mathrm{~B}$ & $9.1 \mathrm{~B}$ \\
\hline Parry's oatgrass/Idaho fescue & $14.3 \mathrm{~A}$ & $-1.18 \mathrm{~A}$ & $350 \mathrm{~B}$ & $6.7 \mathrm{~B}$ \\
\hline Other grasses ${ }^{1}$ & $15.2 \mathrm{~A}$ & $-1.67 \mathrm{~B}$ & $346 \mathrm{~B}$ & $10.8 \mathrm{~B}$ \\
\hline Forbs $^{1}$ & $21.5 \mathrm{~B}$ & $-2.42 \mathrm{C}$ & $226 \mathrm{~A}$ & $28.7 \mathrm{~A}$ \\
\hline SEM & 0.74 & 0.20 & 8.6 & 2.0 \\
\hline \multicolumn{5}{|l|}{ Treatment } \\
\hline Grazed & 16.8 & -1.81 & 314 & 16.0 \\
\hline Ungrazed & 16.4 & -1.78 & 325 & 11.6 \\
\hline SEM & 0.83 & 0.19 & 98 & 1.3 \\
\hline \multicolumn{5}{|l|}{ Source of variation ${ }^{3}$} \\
\hline S & $<0.001$ & $<0.001$ & $<0.001$ & $<0.001$ \\
\hline $\mathrm{T}$ & 0.751 & 0.933 & 0.444 & 0.040 \\
\hline $\mathrm{T} \times \mathrm{S}$ & 0.602 & 0.778 & 0.239 & 0.362 \\
\hline $\mathrm{Y}$ & 0.289 & 0.116 & 0.976 & 0.894 \\
\hline $\mathrm{Y} \times \mathrm{S}$ & 0.243 & 0.767 & 0.013 & 0.053 \\
\hline $\mathrm{T} \times \mathrm{S}$ & 0.651 & 0.600 & 0.691 & 0.618 \\
\hline $\mathrm{T} \times \mathrm{Y} \times \mathrm{S}$ & 0.881 & 0.852 & 0.194 & 0.285 \\
\hline
\end{tabular}

${ }^{1}$ See Methods for a listing of plant species.

${ }^{2}$ Means within a subset of a column with the same uppercase letter, or have no letter, are not different $(P>0.05)$.

${ }^{3} \mathrm{~S}$ indicates species; T, treatment; M, Y, year.

rate of increase over the sampling period (Table 8). Projected ADF concentrations in October were $341 \mathrm{mg} \cdot \mathrm{g}^{-1}$ for forbs and $392 \mathrm{mg} \cdot \mathrm{g}^{-1}$ for rough fescue. All other grass categories were similar $(P>0.05)$ to that of rough fescue (both intercept and coefficient values).

Finally, grazing had no effect $(P>0.05)$ on the average mass of $\mathrm{N}$ or TDN over $2 \mathrm{yr}$ in these rough fescue communities (data not shown). However, in a wet year (2005), $\mathrm{N}$ mass was greater $(P<0.05)$ from June to August $\left(\overline{\mathrm{x}}=3.1 \mathrm{~g} \cdot \mathrm{m}^{-2}\right)$ than in October $\left(1.5 \mathrm{~g} \cdot \mathrm{m}^{-2}\right)$, and in a dry year (2006), $\mathrm{N}$ mass was greater $(P<0.05)$ in July $\left(3.3 \mathrm{~g} \cdot \mathrm{m}^{-2}\right)$ than all other times. TDN remained similar $(P>0.05)$ among months from July to October $\left(\overline{\mathrm{x}}=262 \mathrm{~g} \cdot \mathrm{m}^{-2}\right)$ in 2005 , and from June to August in $2006\left(\overline{\mathrm{x}}=266 \mathrm{~g} \cdot \mathrm{m}^{-2}\right)$. During 2006, TDN was lower $(P<0.05)$ in October $\left(258 \mathrm{~g} \cdot \mathrm{m}^{-2}\right)$ than previous months.

\section{DISCUSSION}

Despite marked changes in plant species composition that appeared to vary with site, grazing history had no clear and consistent effect on either ANPP or forage quality, as defined by their $\mathrm{N}$ and ADF concentrations. However, the most important effect of grazing was to alter litter mass, and therefore the indirect effects that are mediated by litter, including grassland quality. Litter affects various grassland processes including herbivory (Willms et al. 1980a; Moisey et al. 2006) and the soil environment (Deutsch et al. 2010), which may either enhance or diminish productivity. Forage production can be enhanced when soil water is conserved by reducing evaporation, or it may be diminished when litter constrains plant establishment and growth by limiting light penetration, reducing soil temperature (Knapp and Seastedt 1986), or imposing physical constraints through various mechanisms on seeds or plants (Facelli and Pickett 1991). Thus, the results of our study were dictated by disturbances produced either by grazing or protection from large herbivores, and which were mitigated by local site conditions.

Fescue grasslands have a long history of disturbances either through repeated fires or grazing by bison. Grass fires would likely have occurred when fuel was dry, either in spring before too much green growth was present to obstruct fire or after senescence (Kay 1995), whereas most grazing by bison was believed to have occurred in fall and winter (Epp 1994). With disturbances more likely outside of active growth periods (i.e., September through March), fescue grasslands may have evolved to tolerate these disturbances, with dominant plants such as rough fescue that define the character of fescue grasslands generally being more resistant to damage during dormant periods. These findings are supported by studies highlighting the susceptibility of fescue to disturbance during the growing season. Summer grazing by cattle in particular can negatively impact rough fescue vigor (Willms et al. 1985) and leads to replacement of this late seral plant with more grazingtolerant species such as Parry's oatgrass, Idaho fescue, and an assortment of early to midseral forbs. Ultimately, heavy use results in widespread replacement of the native community with more grazing-tolerant introduced grasses such as Kentucky bluegrass, timothy (Phleum pratense L.), and smooth brome (Willoughby and Alexander 2005). Our results suggest that despite ongoing compositional changes, grazed plant communities remained stable in forage availability and quality 
throughout the summer and even into the early fall, in effect compensating for the loss of rough fescue.

Despite its similar forage quality as other associated species in this grassland, rough fescue is an important resource for winter grazing and may supply disproportionately more grazing opportunities than other grasses when snow cover is present (Willms and Rode 1997). Previous work indicates that rough fescue is not the most preferred species in summer or fall when other grass species are available, including Kentucky bluegrass, a common invasive species in fescue grasslands (Moisey et al. 2005). The importance of rough fescue for winter grazing may be due to its strongly tufted growth form and tall stature, making it easier to detect by grazing animals under snow than rhizomatous grasses or shorter tufted species. Therefore, although the shift in species composition induced by grazing to a smaller proportion of rough fescue and a greater proportion of midseral grasses and forbs may have improved selection opportunities for livestock grazing during summer, this same response may have reduced opportunities for winter grazing (Willms and Rode 1997), and merits further investigation.

Litter affects forage selection and the dietary quality of herbivores. Herbivores avoid selecting new plant growth with abundant litter in fescue grasslands (Moisey et al. 2006), which reduces their foraging efficiency and affects their feeding distribution (Willms et al. 1980b). In our study, the proportion of litter to ANPP was about five times greater within ungrazed exclosures than in adjacent grazed communities, and suggests that grazing indirectly enhanced the quality of forage available for herbivores in these grasslands even though the nutrient concentration and nutrient yield of current annual herbage was not altered. The consequence of litter on forage selection may mean that with sufficient litter retention, plant species that are sensitive to summer grazing could avoid severe defoliation and thereby maintain plant vigor.

The positive relationship of litter mass to the proportion and biomass of rough fescue is likely an example of a barrier effect to grazing that benefits this species. The presence of litter in large tufted plants may result in livestock avoiding them and the formation of wolf plants (Ganskopp et al. 1992). When this happens, their avoidance is strengthened, and unless grazing pressure increases, litter continues to accumulate. Within fescue grasslands, ungrazed patches are dominated by rough fescue plants (Willms et al. 1988), and are relatively stable due to protection from a barrier of litter, whereas grazed patches consist of grazing-tolerant plants. This phenomenon has been observed elsewhere, and is often considered problematic because of the loss of usable forage when animals avoid plants with excess litter (Ganskopp et al. 1992). However, in the context of fescue grasslands, litter protection of rough fescue may be an important and valuable conservation strategy for this species, as well as a practical tool to maintain opportunities for winter grazing.

The relative proportion of ANPP comprising rough fescue can also increase if other species were suppressed by litter, which seems to be the case in our study. Heavy litter can reduce forbs and associated grasses, which ultimately results in a loss of species diversity (Willoughby and Alexander 2005). Therefore, although protection from disturbance alone may enhance the proportion of rough fescue, this response may partly arise by reducing the abundance of species competing with it.
Consequently, these grasslands need to be carefully managed with grazing to optimize their potential for conservation of biodiversity and forage production. The mass of litter present on the grazed portion of our study sites was indicative of healthy Foothills Fescue grassland (Adams et al. 2003) and therefore suggests an optimal level of utilization in the past.

The importance of litter in conserving soil moisture was not clearly expressed in this study possibly because of variation in site characteristics, which influence soil moisture and thus the effectiveness of litter. A comprehensive survey of physical characteristics was not made of each site but we may infer from the response of ANPP to grazing or litter that the Waldron site was more mesic than the other four. This is suggested by the relatively high ANPP in the grazed treatment, where we might expect no change or a decrease in production from the ungrazed, and a negative response of ANPP to increased litter, suggesting that litter, which would be suppressed by grazing, and not deficient soil moisture, was constraining production. Aboveground constraints become more prominent as the moisture regime of a site increases (Burke et al. 1998).

\section{IMPLICATIONS}

Despite changes in plant species composition, long-term summer grazing of rough fescue grasslands has led to no changes in the seasonal availability of forage biomass and quality from June through October. However, previous summer grazing at a moderate rate also appears to have conditioned these grassland for subsequent herbivory by removing litter and thereby enhancing animal accessibility to green herbage in spring. This process results in patch grazing and is likely responsible for the $30 \%$ loss of rough fescue biomass we observed, and may reduce the quality of these grasslands for winter grazing, a question beyond the scope of the present study. Although this patchiness creates edge effects and contributes to greater species diversity and structural heterogeneity, increases in the abundance of subdominant grasses, other grasses, and forbs were able to stabilize productivity of this ecosystem under grazing.

\section{ACKNOWLEDGMENTS}

We greatly appreciate the efforts of Barry Adams and Michael Willoughby for assisting with initiating this study. Funding for this study was provided by Alberta Sustainable Resource Development, the Rocky Mountain Forest Range Association and the University of Alberta.

\section{LITERATURE CITED}

Adams, B. W., R. Ehlert, D. Moisey, and R. L. McNell. 2003. Rangeland plant communities and range health assessment guidelines for the Foothills Fescue Natural Subregion of Alberta. Lethbridge, AB, Canada: Rangeland Management Branch, Public Lands Division, Alberta Sustainable Resource Development, Pub. No. T/038. 85 p.

Balley, D. W., J. E. Gross, E. A. Laca, L. R. Rittenhouse, M. B. Coughenour, D. M. Swift, AND P. L. Sims. 1996. Mechanisms that result in large herbivore grazing distribution patterns. Journal of Range Management 49:386-400. 
Burke, I. C., W. K. Lauenroth, M. A. Vinton, P. B. Hook, R. H. Kelly, H. E. Epstein, M. R. Aguiar, M. D. Robles, M. 0. Aguilera, K. L. Murphy, and R. A. Gill. 1998. Plant-soil interactions in temperate grasslands. Biogeochemistry 42:121-143.

Deutsch, E. S., E. W. Bork, And W. D. Willms. 2010. Separation of grassland litter and ecosite influences on seasonal soil moisture and plant growth dynamics. Plant Ecology 209:135-145.

Epp, H. T. 1994. Original range managers: migrant and sedentary grazers. In: F. K. Taha, Z. Abouguendia, and P. R. Horton [EDS.]. Proceedings of the First Interprovincial Range Conference in Western Canada; 17-20 January 1993; Saskatoon, SK, Canada. Saskatoon, SK, Canada: The First Interprovincial Range Conference in Western Canada. p. 142-147.

Facelli, J. M., And S. T. A. PICKett. 1991. Plant litter: its dynamics and effects on plant community structure. Botanical Review 57:1-32.

Ganskopp, D., R. Angell, And J. Rose. 1992. Response of cattle to cured reproductive stems in a caespitose grass. Journal of Range Management 45:401-404.

KAY, C. E. 1995. Aboriginal overkill and native burning: implications for modern ecosystem management. Western Journal of Applied Forestry 10:121-126.

Knapp, A. K., And T. R. SeAstedt. 1986. Detritus accumulation limits productivity of tallgrass prairie. BioScience 36:662-668.

McNaughton, S. J. 1976. Serengeti migratory wildebeest: facilitation of energy flow by grazing. Science 191:92-94.

Molsey, D., And B. A. Adams. 2001. Annual Summary: Rangeland Benchmark Monitoring Program Within the Grassland Natural Region. Lethbridge, $A B$, Canada: Public Lands, Southern Region, Sustainable Resource Development. $154 \mathrm{p}$.

Moisey, D. M., E. W. Bork, And W. D. Willms. 2005. Non-destructive assessment of cattle forage selection: a test of skim grazing in fescue grassland. Applied Animal Behaviour Science 94:205-222.
Moisey, D. M., W. D. Willms, And E. W. Bork. 2006. Effect of standing litter on rough fescue utilization by cattle. Rangeland Ecology \& Management 59:197-203.

Morgan, R. G. 1980. Bison movement patterns on the Canadian plains: an ecological analysis. Plains Anthropology 25:142-160.

WiLLms, W. D. 1991. Influence of summer cutting and fertilizer application on Altai wild rye in winter. Canadian Journal of Plant Science 72:173-179.

Willms, W., A. W. Bailey, and A. McLean. 1980a. Effect of fall burning or fall clipping bluebunch wheatgrass (Agropyron spicatum) on the spring foraging behavior of mule deer (Odocoileus hemionus hemionus) and cattle. Journal of Applied Ecology 17:69-84.

Willms, W., A. W. Balley, A. McLean, and R. Tucker. 1980b. The effects of fall defoliation on the utilization of bluebunch wheatgrass and its influence on the distribution of deer in spring. Journal of Range Management 34:16-18.

Willms, W. D., J. F. Dormaar, and G. B. Schaalde. 1988. Stability of grazed patches on rough fescue grasslands. Journal of Range Management 41:503-508.

Willms, W. D., And L. M. Rode. 1997. Forage selection by cattle on fescue prairie in summer or winter. Journal of Range Management 51:496-500.

Willms, W. D., S. Smoliak, AND J. F. DormaAR. 1985. Effects of stocking rate on rough fescue grassland vegetation. Journal of Range Management 38:220-225.

Willoughby, M. G., and M. J. Alexander. 2005. Long-term trends in rangeland health of the rough fescue ecological site in the Montane Subregion. Edmonton, AB, Canada: Alberta Sustainable Resource Development, Public Lands and Forests Division Pub No. T/069. 20 p.

Willoughby, M. G., M. J. AleXander, and B. W. Adams. 2005. Range plant community types and carrying capacity for the Montane Subregion of Alberta. Edmonton, AB, Canada: Rangeland Management Branch, Public Lands Division, Alberta. Sustainable Resource Development Pub. No. T/071. 248 p.

Wright, H. A., AND A. W. Balley. 1982. Fire ecology: United States and southern Canada. New York, NY, USA: John Wiley and Sons, Inc. 501 p. 